\title{
Decentralization of Marine Resource Management by Local Government for Realization of Indonesian People Prosperity
}

\author{
Rosita Candrakirana ${ }^{1,2}$, Tri Hayati ${ }^{2}$ \\ $\left\{\right.$ rositakirana@yahoo.com $\left.{ }^{1}\right\}$ \\ Universitas Sebelas Maret, Indonesia ${ }^{1}$, Universitas Indonesia ${ }^{2}$
}

\begin{abstract}
Indonesia has potential natural resources that can be found in its maritime and lands territories. As an archipelago, territories of Indonesia are mostly seas, namely two-thirds of the country area. In managing the territories, the state delegates mandated to central government assisted by local governments. Authority of local government in running their affairs based on principle of regional autonomy is regulated by Article 18 of the 1945 Constitution of The Republic of Indonesia. Implementation of marine resource management by local governments was regulated in several phases of Local Government Act with three times of revision, namely Law No. 22 of 1999, Law No. 32 of 2004 to Law No. 23 of 2014 on Local Government. Central Government tried to find and organize appropriate management of marine resource in attempt of realizing Indonesian people prosperity.
\end{abstract}

Keywords: Territories of Indonesia, Local Governments, Constitution of The Republic of Indonesia

\section{Introduction}

International Potential natural resources of Indonesia can be found in sea and land territories of the country. As an archipelagic country, the geographical condition of Indonesia is mostly maritime territories representing two-thirds of the entire territory of Indonesia. [1] In addition, Indonesia is the largest archipelagic country of the world with abundant natural resources and potential as a gift from God Almighty, and the sea has a unifying meaning, namely to connect islands in an unity of ideology, political, economy, social, cultural, defense and security in territorial space of the Unitary State of the Republic of Indonesia [2].

Based on physical facts, Indonesia is the largest archipelagic country of the world consisting of 17,504 islands [3] with seawater area of 5.8 million $\mathrm{km} 2$ (consisting of 0.3 million $\mathrm{km} 2$ territorial maritime, 2.95 million km2archipelagic waters, and 2.55 million $\mathrm{km} 2$ EEZ) [3] and Indonesia has the second-longest coastline after Canada, namely $99.093 \mathrm{~km} 2$ (BIG, 2016) [4]. With this physical condition, Indonesian territory is mostly ocean, and as a logical consequence of such picture, Indonesia is not only attractive but also very strategic viewed from various aspects because it has remarkable biological, non-biological, cultural, ethnic as well as potential economic diversity [5]. Indonesian people should collectively protect the marine legacy with full integrity. Suboptimal management of the sea results in a little contribution of the marine sector to the development and welfare of the people. 
A review of the Corruption Eradication Commission on Natural Resources in the maritime sector indicated that non-tax state revenue (PNBP) contribution was found to be only an average of 0.3 percent per year. For example, contribution of PNBP from fisheries sector in last five years was only 0.02 percent of the total national tax revenue [6]. For this reason, fishermen of Indonesia are still considered as a community group with the highest level of poverty. In line with the review, a study by the Ministry of Fisheries and Maritime Affairs (KKP) showed that residents of coastal areas dominated the number of poor people in Indonesia. The number is now reaching 7.9 million people or 25 percent of the total number of people [7]. The finding builds awareness of suboptimal management of marine sector so far.

The government should have more strategic role of in order to maintain and conserve marine resources to meet the needs and livelihoods of citizens [8]. Eleven marine economic sectors can be developed for progress, prosperity and self-sufficiency of the Indonesian people. The 11 marine economic sectors are: (1) natural fishery, (2) aquaculture fishery, (3) industry of fishery product processing, (4) industry of marine biotechnology, (5) mining and energy (ESDM), (6) coastal (coastal forestry), (7) maritime tourism, (8) sea transportation, (9) maritime industry and services, (10) resources of small islands regions, and (11) nonconventional marine resources [9]. Problem of the potential development is suboptimal management of resources in coastal and oceanic areas. According to Rokhmin Dahuri, potential economic value of the 11 marine economic sectors in 20017 was estimated to reach US 1.35 trillion per year [10]. Meanwhile, employment opportunities can be created for about 45 million people [11]. Therefore, if we are able to exploit the marine economic potential productively, efficiently, fairly and environmentally, the problem of unemployment and poverty will automatically be solved.

In 2017, contribution of maritime sector to GDP was $11 \%$ [12], namely GDP of the maritime and fisheries sector was recorded at Rp 84.4 trillion [13]. Thus, government authority is very necessary in managing natural resources, especially marine resources regulated in Article 33 paragraph (3) of the 1945 Constitution of the Republic of Indonesia mandating that natural resources are controlled by the state and used to the greatest prosperity of the people. Article 33 paragraph (3) is a legal source as well as a legal basis for each regulation controlling management of natural resources, especially in studies concerning marine resources. Furthermore, authority of regional governments in carrying out their affairs based on the principle of regional autonomy has also been regulated in Article 18, $18 \mathrm{~A}$ and 18 B of the 1945 Constitution of the Republic of Indonesia. As contained in Article 18 paragraph (1) and (5) of the 1945 Constitution, autonomous regions such as provinces, regencies and municipalities are established. The regional governments carry out autonomy as widest as possible [14], except for governmental affairs that the law stipulates central government to handle them. Based on the background above, it is important to study the problem of how management of marine resources by local government in attempt of realizing people prosperity.

\subsection{Local Government}

According to Bhenyamin Hoessein the concept of local government can serve three meanings. First, it means local government. Second, it means local administration carried out by a local government. Third, it means an autonomous region [15]. The first Local Government refers to an institution/organ. The point is local government is an organ/body/government organization at regional level or an establishment with task of organizing administrative activities in a specific area. Local government of the second sense refers to its function/activity. The meaning of local government is the same as regional 
government. In Indonesian context, local government is distinguished by the term regional government. Regional government is an agency or organization in its more passive form, while local government is the active form. In other words, regional government is an activity carried out by local government [16]. Local government according to the third sense as an autonomous region, it can be examined in a definition established by the United Nations Public Administration, namely national political subdivisions regulated by law and substantially have control over local affairs, including the power to collect taxes or fire employees for specific goals [16]. In this sense, local government has (local) autonomy, in the sense of self-government. That is an authority to regulate (rules making = regelling) and take care of (real application = bestuur) the interests of local community according to its own initiative [17].

\subsection{Decentralization}

Regional autonomy is the essence of a decentralized government. The term autonomy comes from two Greek words, namely "autos" means itself and "nomos" means law. Autonomy means making its own legislation (zelfwetgeving), but in its development the concept of regional autonomy has been, in addition to the meaning zelfwetgeving (the local regulation making), also mainly including zelfbestuur (self-government). C.W. van der Pot identifies the concept of regional autonomy as eigen huishouding (running one's own household) [18].

The concept of regional autonomy can only be applied in a decentralization principlebased government system. With an underscoring that the decentralized government is part of a unitary state (eenheidsstaat). The word decentralization comes from two Latin words, 'de' means "loose" and 'centrum' means "center". Literally, decentralization means to loose from the center. In a constitutional study, governance based on the principle of decentralization adheres to relationship between central government and regional government. The central government delegates some of its authority to regional governments. According to R. Tresna, it is to equate relationship between central government and regional government in a gedecentraliseerd unitary state. The concept of decentralization, according to Brian C. Smith, is that the extent to which power and authority is handed over through a hierarchy geographically within the state and also, it is regarding to institutions and processes allowing the distribution to take place. Decentralization requires division of territories of the country into smaller areas and the establishment of administrative and political institutions in those areas. Decentralization encompasses various types of hierarchies which are a combination of different institutions and functions. Every level of government in a unitary or federal state can delegate power to a lower level of government [19]

\section{Method}

The present study refers to opinion that a normative legal research is a procedure of scientific research to find the truth based on legal science logic of its normative aspect. The rigorous logic of science in normative legal research is built on scientific disciplines and normative legal methods of work, namely the legal science with the law itself as its object [20]. In this case, the study of positive legal research has several labels that actually have the same meaning, namely doctrinal study [21]. The doctrinal legal research (doctrinal study) is basically a library-based study, materials needed by researchers are found in libraries, archives and other databases. The basic purpose of this research is to find, explain, discuss, analyze and present the facts, principles, decisions, concepts, theories or working on certain laws or legal 
institutions systematically. An underlying goal of the research is to achieve and present new knowledge and ideas or to suggest change and improvement [22]. The study uses document study examining primary, subsidiary and tertiary legal materials. Data analysis of the research is qualitative data analysis, namely collecting and qualifying the data, and then, linking theories related to the problem and finally, drawing conclusion to determine the result.

\section{Result and Discussion}

Management of marine resources by local governments has undergone various changes of provisions since before reform era to after the era. Provisions governing decentralization of authority in managing marine resources by local governments was found in the reform era. The regulation can be found in the 1945 Constitution of the Republic of Indonesia concerning regional autonomy, and it is the basis for the existence of the Local Government Law starting from Law No. 22 of 1999, Law No. 32 of 2004, and Law No. 23 of 2014. The three laws regulate the journey of authority in managing natural resource, especially marine resources management by provincial and regency/municipal governments. An explanation of authority delegated to provincial and regency/municipal governments in management of marine resources is as follows:

1) Law No. 22 of 1999 on Local Government

Very basic governance established and contained in the Law of Local Government for the first time was autonomy in management of marine resources determining range of authority up to 12 miles for provincial marine area and one third of the provincial sea boundaries for regency/municipal area. Regional authority in that maritime zones includes: a) exploration, exploitation, conservation and management of marine resources as far as 12 nautical miles; b) Regulation of administrative interests; c) Spatial planning; d) Law enforcement for regulations issued by Local Government or authority that are delegated by Central Government; e) Assistance Task in enforcing state security and sovereignty, especially in the sea.

2) Law No. 32 of 2004 on Local Government

In this law, local governments were granted with authority to regulate the use of marine resources in their own regions. Article 18 of Law No. 32 of 2004, explicitly granted the authority to Regions. The authority of marine resource management covering up to 12 nautical miles from the coastline to the open sea for provincial government and one third of the sea boundary or 4 nautical miles for regency/municipal governments consists of: a) exploration, exploitation, conservation and management of marine resource; b) administrative interests; c) spatial planning; d) law enforcement for regulations issued by local government or those that are delegated by central government; e) assistance in enforcing state security and sovereignty, especially at sea; f) participation in maintaining state sovereignty. If maritime zone between two provinces is less than 24 (twenty four) nautical miles, the authority of managing marine resources of the sea area shall be divided equally or measured according to the midline principle of the region between the two provinces.

3) Law No. 23 of 2014 on Local Government

The law states that Local Government is granted authority of Provincial Region in managing marine resources at the range of 12 (twelve) nautical miles measured from coastline towards the open sea and/or towards islands waters. Authority of marine resource management shall be divided equally or measured according to the midline principle of area between the two provinces. Provincial authority of marine resource management includes: a) exploration, exploitation, conservation and management of marine resources, except for oil and natural gas; b) administrative regulation; c) spatial planning; d) participation in maintaining security at sea; e) Participation in the defense of state sovereignty. The law governs provincial 
regions characterized with Islands to have similar authority of marine resource management as the Provincial Region with the sea. In addition to having such authority, the archipelagic provincial regions have an assignment from the Central Government in the field of maritime affairs based on the principle of Assistance Task.

Process of the making and content of the three laws concerning regional administration during reform era were influenced by different backgrounds. A very prominent background regarding the Law on Local Government before the reform era, namely Law No. 5 of 1974 concerning Principles of Regional Government, was its centralistic color in which a footdragging was found between the interests of central government and those of regional governments [23]. It is because the law was not governing authority of provincial administration and regency/municipal administration in managing marine resources. Therefore, the central government established and enacted Law No. 22 of 1999 concerning Regional Government. Basically, the Law stipulates that Provincial, Regency and Municipal governments hold all authorities. Thus, the enactment of Law No. 22 of 1999 tends to make a pattern of authority will larger in low levels to form an up-side down pyramid [24]. Very basic governance that was established and contained in Indonesia legislation for the first time, namely in the Law No. 22 of 1999 concerning autonomy in management of marine resources stipulating authority reaching 12 nautical miles as measured from coastline to the open sea and/or towards archipelagic waters and 12 nautical miles from coastline to the open sea for provincial regions and one-third of the provincial marine area for Regency/Municipal Regions [24].

Implementation of decentralization in Indonesia experienced significant development since enactment of Law No. 22 of 1999 with its broad autonomy, especially decentralization in management of marine resources. It is because the Law No. 22 of 1999 limited administrative affairs in central and provincial levels through Government Regulations. No. 25 of 2000 concerning Authority of Government and Authority of Provinces as Autonomous. Mechanism of the administrative affairs distribution followed the concept that residual functions are submitted to regency/municipal levels, while administrative affairs at central and provincial levels are clearly and specifically stipulated as outlined in Government Regulation 25 of 2000. Considering the residual functions submitted to regency/municipal administration had very broad scopes, so it provided impression that regency/municipal governments referred to principle of broad autonomy or general competence [25], whereas the limited autonomy (ultra vires) was at the provincial level.

The large scale of governmental affairs that were delegated to local governments led to consideration that the Law was bringing Indonesia closer to federation system. The central government considered Law No. 22 of 1999 was dominant with decentralization [23]. Reasons indicating the weaknesses of the Law No. 22 of 1999, are, among the others [26]:

- Base of autonomy that is in regency/municipal levels and not in provincial level is actually posing a threat to management of natural resources and environment;

- Authority to determine policy of natural resources allocation and licensing is in the hand of the Regent/Mayor. It limits the right of people to determine what suits their needs;

- Implementation of authority and responsibility in managing natural resources and environment by local governments is not accompanied by obligation of providing quality budget and expert staff to oversee the implementation of protection and management of natural resources/ environment in areas concerned.

The reasons above were a background of changing the Law No. 22 of 1999 to the Law No. 32 of 2004 concerning Local Government. The new law was considered to begin a process of 
withdrawing governmental affairs that had been delegated to local administrators. The central government considered Law No. 32 of 2004 presents a balance between centralization and decentralization. Law No.32 of 2004 tries to clarify the distribution of governmental affairs and remains in the corridor of broad autonomy (general competence) that is found in regional level both at provincial and regency/municipal levels. Government Regulation No. 38 of 2007 concerning Distribution of Government Affairs between Central Government, Provincial Government, and Regency/Municipal Governments as derivative of the Law No. 32 of 2004 attempted to distribute government functions between central, provincial and regency/municipal governments. Act No. 32 of 2004 still grants authority of marine resources management to provincial and regency/municipal governments. This Local Government Law tries to limit the authority of local governments in managing marine resources by clarifying division of governmental affairs in maritime and fisheries fields.

Many societies consider that management of marine resources in Indonesia is not optimal yet. In fact, it raises many problems such as social conflicts between fishermen who live in adjacent regency/municipal regions and it causes various damage to marine environment. It is because regency/municipal governments are competing to earn local revenue (PAD) from management of marine resources. The Law No. 32 of 2004 is revised because it is more oriented to coastal resource exploitation in regency/ municipal levels without regard to preservation of natural resources. In addition, there is a lack of awareness of strategic value that can be created from sustainable, integrated and community-based coastal management [25].

An effort of reorganization is conducted in the implementation of marine resources management by the central government with revision of Law No. 32 of 2004 to Law No. 23 of 2014 concerning Local Government. The new Local Government Law contains particularities for the Forestry and Maritime Sector as well as Energy and Mineral Resources [27]. Act No. 23 of 2014 experienced a very significant change in the management of marine areas by the local government. the changes are [27]:

a. Change of authority

Based on Article 27 paragraph (1) of the Local Government Law, Provincial Region is granted authority to manage marine resources in its own territory. That is, the article stipulates that only the province that has the right to manage marine resources. It is different from previous rule stipulating that regions with marine areas shall be granted authority to manage resources in the marine areas (Article 18 paragraph 1 of Law No. 32 of 2004). What is meant as Regions in this article are Province and Regency/Municipal ones? Thus, Article 27 paragraph (1) of the Local Government Law revokes the authority of Regency/Municipality.

b. Sharing the revenue of resource management

Dispossession of regency/municipal authority in natural resources management of the sea causes a new arrangement regarding revenue sharing. This revenue sharing is given to producer regency/municipality and not to those who get earning from holding administration of governmental affairs. The producer regency/municipal regions determined for the marine revenue sharing are those with marine products obtained within 4 (four) nautical miles area measured from the coastal line to the open sea and/or towards archipelagic waters. In the case that two regencies/municipals have boundaries of less than 4 (four) nautical miles, territorial boundaries shall be divided equally for the distance or measured according to the midline principle of the border areas. This means that regency/municipal governments are still having the "right" of resource sharing for production obtained in the range of 4 nautical miles maximally. 
c. Province Characterized by Islands

Pursuant to Article 28 paragraph (1) of the Law on Local Governments, archipelagic provinces are, in addition to exercising authority of marine resources management in their own areas, also assigned by the Central Government to exercise its authority in maritime sector. The assignment will only be able carried out if the archipelagic provinces meet qualification of norms, standards, procedures and criteria set by the Central Government. Regarding the norms, standards, procedures and criteria, the Local Government Law mandates regulation to be in the form of Government Regulation.

Based on various consequences resulted from the change in authority of marine resources management from regency/municipal government to Provincial one, it is theoretically contrary to the intent of decentralization. Decentralization has a meaning of making a closer social gap between policy makers and the public who will be affected by impact of policies. Policy makers will feel direct impact of their policies. Therefore, it is expected that policies taken will be more in line with actual reality and also, there is greater space for public participation. It is an anti-thesis of centralization of resource management that does keep their social gap away. As a result, centralization is potentially ignoring diversity of conditions and aspirations so that policies taken may not be in accordance with local conditions [28].

Enactment of Regional Government Act No. 23 of 2014 concerning Local Government is intended to correct deficiencies of previous law, in which local government is structured by bringing together the spirit of local democracy model and efficiency model. Transfer of authority is changed to a division of governmental affairs based on principle of externality, accountability, efficiency and national strategic interests. Autonomy in provinces is no longer limited, so the autonomy is no longer emphasized in regency/municipality.

Re-assignment of the authority of marine resource management as stated in the Local Government Law to provincial government in concurrent administrative affairs [29] are based on principle of decentralization and principle of Assistance Task. Change of authority hold by regency/municipal governments in management of natural resources, especially in marine sector due to the Law No. 23 of 2014 will bring harm to natural resources, especially those located in regency/municipality. Some potential losses will occur, among the other [30]:

- Reduced awareness of regency/municipal governments to protect and manage environment and natural resources especially in marine sector of their regions;

- Function of guidance and supervision will not optimal for management of natural resources of marine sector in regency/municipality;

- An increased potential conflict between provincial governments and regencies/ municipal ones with regard to management of natural resources of marine sector.

From description above, the authority journey of marine resources management in Indonesia in the reform era with decentralization can be seen, although Indonesia is a unitary state where sovereignty of the state is single and not spread among states such as in a federal state. Thus, governmental system in a unitary state is basically centralization or, euphemistically, de-concentration. However, considering very broad territories of Indonesia consisting of tens of thousands of large and small islands and its population consisting of various ethnic groups, classes and religions, thus in accordance with Article 18, $18 \mathrm{~A}$ and 18 $\mathrm{B}$ of the 1945 Constitution, administration of government is not through centralization but decentralization [31]. Adoption of the concept of decentralization has experienced fluctuations with 3 times changes in the Local Government Law, namely 1999, 2004 and 2014. In every the change, there was issue in implementation, especially with regard to authority of marine resource management. The foot-dragging relating to authority of marine resource management from regency government to province one indicates that regional autonomy has been running 
inefficiently and ineffectively so far. According to Prof. Djohermasyah Djohan, regional autonomy is a certainty in national and state life history. It is due to the core of regional autonomy concept is the closer the government to the people the better the service, and it is the most appropriate way for government to find accelerative efforts in order to achieve people prosperity and welfare [32].

Thus, regulation regarding marine resources management should be in accordance with the concept of regional autonomy emphasizing the closer existence of government to communities. The existence of the central government represented by regional government is "to encourage democracy or citizenship and to promote political education." [33] In that matter, Stewart emphasized "Local Government is not just a matter of delivering services to the public, it is about making choice for a locality [34]." Therefore, development of local government should be based on local democracy (local voice and local choice). In addition, politically decentralization can strengthen accountability (political responsibility), political skills and national integration. Decentralization brings the government to be closer to the people. Decentralization provides better services to community groups. Decentralization promotes freedom, equality and prosperity [35]. Thus, regional autonomy is not a goal but an instrument to achieve goals [36][36].

\section{Conclusion}

Regulation of marine resource management in Indonesia experienced many phases of change from 1999 to 2014. Decentralization of marine resources management arose from the reformation era until now. The most recent applied regulation, the Law No. 23 of 2014 concerning local Government, is still facing problems, namely handover of authority in managing marine resources from regency/municipal governments to provincial government. The regulation appears to make regency/municipal governments do not have autonomy in management of the sea. However, as it is examined with the concept of regional autonomy, namely decentralization or delegation of regional affairs from central government to those that are closer to communities, so regulation revoking authority of regency/municipal governments in managing the sea is in contrast to Article 18 of the 1945 Constitution that is regulating regional governance. Furthermore, it also does not comply with the concept of regional autonomy, namely the closer the government to the people the better the service. It can be an evaluation for legislators who make regulations of local government and central government in implementation of the local government law of 2014, which has been turned out to cause potential losses for regency/municipal governments.

\section{References}

[1] Marhaeni Ria Siaombodo, Hukum Perikanan Nasional dan Internasional. 2010: PT Gramedia Pustaka Utama.

[2] K. RI, "The Republik of Indonesia, Marine Act, law No32 of 2014, LN of 2014 No. 294, TLN No. 5603.," 2014 . .

[3] "Performance Report of Marine and Fishery Ministry of," p. 8, 2017.

[4] Kelautan, Statistics of Marine and Coastal Resource. Jakarta: Badan Pusat Statistik, 2017.

[5] Herman Khaeron, Transformasi Politik Kelautan Indonesia Untuk Kesejahteraan Rakyat. Jakarta: Pustaka Cidesindo, 2012.

[6] Kpk, "Selamatkan SDA kelautan." .

[7] kabar bisnis, "Penduduk miskin tinggal di kawasan pesisir." . 
[8] M. Ismail, "Implementasi Program Pelestarian Sumberdaya Kelautan Dan Perikanan Di Kabupaten Situbondo," J. Rev. Polit., vol. 3, no. 2, p. 169-170., 2013.

[9] Rokhmin Dahuri, "Ekonomi Indonesia Ke 'Laut' Saja," Majalah Excellent, 2013.

[10] M. Sekjen, Satuan Kerja Dewan Kelautan Indonesia. Jakarta, 2012.

[11] Rokhmin Dahuri, "Ekonomi Kelautan, Mesin Pertumbuhan Baru," Kompas, 2017.

[12] Kompas.com, "INA/LKT/HEN/MED, Sektor Maritim Menjadi Fokus," 2017.

[13] Muhammad Fajar Marta, "KKP Ajak Universitas Bangun Perikanan Nasional, Kompas," 2017.

[14] Sekjen MPR RI, Risalah Perubahan Undang-Undang Dasar Negara Republik Indonesia Tahun 1945: 1999-2002 Tahun Sidang 2000, 7th ed. Jakarta: Sekretariat Jenderal MPR, 2008.

[15] Bhenyamin Hoessein, Perubahan Model, Pola, dan Bentuk Pemerintahan Deaerah: Dari Era Orde Baru ke Era Reformasi. Depok: Departemen Ilmu Administrasi Fakultas Ilmu Sosial dan Ilmu Politik Universitas Indonesia.

[16] Hanif Nurcholis, Teori dan Praktik: Pemerintahan Dan Otonomi Daerah. PT Grasindo Widiasarana Indonesia, 2007.

[17] D. Safri Nugraha, Hukum Administrasi Negara. Depok: CLGS-FH UI, 2007.

[18] Laica Marzuki, Berjalan-jalan di Ranah Hukum. Konstitusi Pers, 2005.

[19] Brian C. Smith, "Decentralization : The Territorial Dimension of The State.".

[20] J. Ibrahim, “, 2006, Teori dan Metodologi Penelitian Hukum Normatif, Malang: Bayumedia Publishing," p. 318, 2006.

[21] H. Terry, Researching and Writing in Law. Pyrmont NSW: Lawbook Co, 2002.

[22] Y. Anwarul, Legal Research and Writing. Malaysia: Lexis Nexis, 2011.

[23] R. Simarmata and A. Yunan F, "Pemberlakukan Undang-Undang No. 23 Tahun dan Desentralisasi di Bidang Pengelolaan Sumber Daya Alam (: Perkumpulan Untuk Pembaharuan Hukum Berbasis Masyarakat dan Ekologis (HUMA), 2016), p. .," p. 7, 2014.

[24] H. A. . Natabaya, Analisis Evaluasi Hukum Tentang Otonomi Daerah Dalam Kaitannya Dengan Wilayah Pesisir dan Laut. Jakarta: Badan Pembinaan Hukum Nasional Departemen Hukum dan PerUndang-Undangan RI, 1999/2000, 1999.

[25] D. Hadi Supratikta, Laporan Akhir Pengkajian Hukum Tentang Pembagian Kewenangan Pusat dan Daerah Dalam Pengelolaan Laut. Jakarta: Pusat Penelitian Pengembangan Sistem Hukum Nasional kementerian Hukum dan Hak Asasi Manusia RI, 2015.

[26] D. Kuntoro, Harmonisasi Hukum Tentang Kewenangan Daerah Di Wilayah Laut. 2004.

[27] A. Lucky and S. Akhmad, Review Terhadap Revisi Undang-Undang 32 Tahun 2004 Tentang Pemerintahan Daerah, Conservation International-Indonesia. 2014.

[28] A. Satria, "Kelautan Setelah Ada Undang-Undang Pemerintahan Daerah," kompas, 2016.

[29] F. Z. Joseph, State and Local Government. New York, Hagerston, San Fransisco, London: Barnes \& Noble Books, 1970.

[30] R. Yanis, "Kewenangan Kabupaten/Kota Dalam Pengelolaan Sumber Daya Alam Di Aceh Pasca Lahirnya Undang-Undang Nomor 23 Tahun," in Prosiding Seminar Nasional Hukum Lingkungan "Pengelolaan Sumber Daya Alam," 2014.

[31] D. Sirajudin, Hukum Administrasi Pemerintahan Daerah. Malang: Setara Press, 2016.

[32] D. Djohermansyah, Merajut Otonomi Daerah Pada Era Reformasi (Kasus Indonesia). 2016. 
[33] B. Tony, Local Government in Britain. London: Penguin Books, 1981.

[34] J. Stewart, Democracy and Local Government in Reinventing Democracy. Cambridge: Blackwell Publisher, 1996.

[35] Mass, D. M. Hill, and B. C. Smith, Decentralization: The Territorial Dimension of The State, UK. Inggris: Translated by Team Public Administration Society of Indonesia, Jakarta Selatan: Masyarakat Ilmu Pemerin 1959;1974. Jakarta Selatan: George Allen \& UNWIN, 1985.

[36] J. Kaloh, Mencari Bentuk Otonomi Daerah Suatu Solusi Dalam Menjawab Kebutuhan Lokal dan Tantangan Global. Jakarta: PT Rineka Cipta, 2007. 